\title{
Limited Liability Companies in the Slovak and European Legal Context
}

\author{
Lenka Vačoková ${ }^{1}$
}

\begin{abstract}
This paper analyses provisions of a Limited Liability Company under the Slovak Commercial Code, mainly conditions governing the process of foundation and incorporation of the company and the structure of company bodies. Legal provisions of the Limited Liability Company are primarily compared with Private Limited Company by Shares established according the Companies Act 2006 and secondarily with proposal for a Directive of the European Parliament and of the Council on single-member Private Limited Liability Companies. The result of the research is a comparison of the Slovak and the British legislation and an effort to predict the future development of Private Limited Liability Companies in the European area.
\end{abstract}

\section{Key words}

Limited Liability Company, Private Limited Company by Shares, foundation and incorporation of the company, Memorandum of Association, Articles of Association, company bodies, director, General Meeting, Supervisory Board

\section{JEL Classification: K2, K22}

Received: 28.6.2018 Accepted: 26.10 .2018

\section{Introduction}

A Limited Liability Company is the most popular business company in the Slovak republic. According to the statistics of the number of newly established business companies in Slovakia in 2017, $92 \%$ of newly established companies have the form of Limited Liability Company, only $1 \%$ of these companies have the form of Joint Stock Company. (Finstat.sk, 2018) One of the main advantages is liability of participants limited to the outstanding part of their pledged contributions registered in the Commercial Register, the amount of the participant's contribution must be at least 750 EUR. A company with full legal capacity is liable for any breach of its obligation with its entire property. ( $\$ 106 \mathrm{CC})$ The minimum amount of the company's registered capital is 5000 EUR. ( $\$ 108(2) \mathrm{CC})$

English law provides two main types of organisation for those who wish to associate $i$ to carry on business for profit, partnerships and companies. Historically, the word company was applied to both, but the modern lawyer regards companies and company law as distinct from partnerships and partnership law. The Companies Act have long provided a form of the company which may be regarded as particularly suitable for companies which carry on a no profit activities. This is the Company Limited by Guarantee, as

1 JUDr. Lenka Vačoková, PhD., University of Economics in Bratislava, Faculty of Commerce, Department of Business Law, Dolnozemská cesta 1, 85235 Bratislava, Slovak republic, e-mail: lenka.vacokova@euba.sk 
opposed to the Company Limited by Shares, the latter being the form normally used for profit-making activities and by far the more common one. The Company Limited by Guarantee is widely used by charitable and quasi-charitable organisations (such as schools, colleges) since incorporation with limited liability is often more convenient and less risky than a trust. The distinction between public and private companies is embodied in the Companies Act. A private company must not offer to the public any of its securities. However, unlike in many continental European countries, there is no separate legislation for public and private companies. (Davies, Worthington, 2012)

Private Limited Company by Shares under the Companies Act 2006 are widely extended in European area due to the informal way and speed of incorporation and low capital, a highly stable legal environment of the United Kingdom, a sophisticated system of electronic filling and tax returns, including a developed network of double taxation treaties. (Pala, 2004, CEVE.Cz, 2013) Aforementioned advantages made Private Company Limited by Shares one of the most preferred form of companies with limited liability in the European Union, which must have registered office in the United Kingdom, but business activities can be carried out in any member state of the European Union (Málek, 2018)

The main reason why we choose the most common business company in the Slovak republic and one of the most frequent used company in the European region is that results of this comparison would probably show possible improvements and suggestions to the Slovak legislation.

In 2014 came up European Commission with proposal for Directive of the European Parliament and of the Council on single-member Private Limited Liability Companies (thereinafter only "proposal"). The overall objective of the proposal, which provides an alternative approach to the 2008 proposal for a European Private Company Statute (SPE) is to make it easier for any potential company founder and for small and medium-sized enterprises (SMEs), to set up companies abroad. The proposal would facilitate crossborder activities of companies by asking member states to provide in their legal system for a national company form that would have an EU-wide abbreviation - SUP (Societas unius personae) and would be formed and operate in compliance with the harmonised rules in all member states.

The Commission in its Work Programme 2018 announced that the proposal will be withdrawn, which it formally did on 3 July 2018. (De Grandes Pascual, 2018) According to this comparison with the proposal will be just informative and marginal. The main interest of this paper is concentrated on comparison of Limited Liability Companies according to the Commercial Code with Private Limited Companies by Shares under the 2006 Companies Act.

\section{Literature review}

Limited Liability Company is the most frequently used form of business companies in the Slovak republic. Therefore there are a lot of sources concerning the process of foundation and incorporation of the company and the structure of company bodies, for example Patakyová, 2016, Suchoža, 2016, Ovečková, 2012. The literature of Czech authors can be used, due to the fact that the Slovak Commercial Code and the Czech 
Commercial Code were similar until the Business Corporations Act 2012 has been adopted, for example Eliáš, Pokorná, Dvořák, 2010 or Pelikánová, Černá, 2006.

Detailed comparison between Limited Liability Company and Private Limited Company by Shares can be found in the journal paper of Baňouch, 2001. This comparison is based on the Companies Act 1985 meanwhile the Companies Act 2006 has been adopted. British company law is detailed for instance in Hannigan, 2016, Davies and Worthington, 2012, Dignam and Lowry, 2014 and European corporate law in Dorrestein, Monteiro, Teichman and Werlauff, 2009. The process of establishment and incorporation of Private Limited Companies is also contained on the website GOV.UK, 2018, to the fact that Private Limited Companies can be registered with the Companies House online. This website concerns actual and substantial information and template of Memorandum of Association and Articles of Association, too.

\section{Methodology}

The aim of this paper is to compare Limited Liability Company under the Commercial Code and Private Limited Company according to the 2006 Companies Act. The comparison concerns conditions of foundation and incorporation of the company and the structure of company bodies. Proposal for a directive of the European Parliament and the Council for one-single member Private Limited Liability Company (SUP) will be just supplementary.

The main objects of the paper are Limited Liability Companies and Private Limited Companies. There are two types of Private Limited Companies in the United Kingdom Private Companies Limited by Guarantee and Private Company Limited by Shares. Only the second one will be the object of our research.

The main methods of scientific research used in this paper are method of analysis and comparative method. Supplementary scientific methods applied in the paper are method of deduction, method of induction and method of synthesis.

We will analyse conditions and the process of foundation and incorporation of the companies and company bodies. Afterwards we will compare both objects of research.

The proposal of single-member Limited Liability Companies will be compared, too. We will also try to predict a future direction of Limited Liability Companies in the European Union.

\section{Results and discussion}

\subsection{Foundation and incorporation}

Limited Liability Company may be established by one person, a natural person or legal entity, maximum numbers of shareholders is 50 . The minimum shareholder's contribution is 750 EUR and the minimum company's registered capital is 5000 EUR. (§ 108, 
109 CC) Before filling the application for the company's registration in the Commercial Register every pledged contribution must be paid up by no less than $30 \%$. The paid-up contributions in cash together with the value of the contribution in kind which have been handed over to the company must create at least $50 \%$ of the minimum amount of the company's registered capital. (§ 111 (1) CC)

If there is only one founder of the company, registered capital must be fully paid before its registration. ( $§ 111$ (2) CC) Single-member Limited Liability Company may not be the only founder or the only participant of another company. A natural person may be the only participant in three partnerships or companies at the most. (§ 105a CC)

Private Limited Company by Shares registered in the United Kingdom must have at least one shareholder, maximum number of shareholders is not specified. The price of individual share can be interesting for shareholders and they can choose low share value, for example $1 £$ to limit their liability. (GOV.UK, 2018) The minimum capital requirement for the Private Company Limited by Shares is $1 £$, usually $100 £$ is recommended. (Ltdcompany.co.uk, 2018) Statement of capital and initial shareholdings must state the total number of shares and the aggregate nominal value of the shares to be taken on formation by the subscribers to the memorandum, the aggregate amount, if any, to be unpaid on those shares, for each class of shares prescribed particulars of the rights attached to them, the total number of shares of that class and the aggregate nominal value of those shares. (Hannigen, 2016) The statement of capital is a useful innovation in the CA 2006 which provides important information as to the structure of the company. The share structure is important in terms of establishing how much share capital has been raised and how much is paid and unpaid and identifying the rights attached to the shares where there are classes of shares. Most companies have only one type of share, an ordinary share, such as the 1f share and class rights are irrelevant in such a company. (Hannigen, 2016)

Here is the fundamental difference between Limited Liability Company and Private Limited Company by Shares. Shares of the Limited Companies (private or public) are of the same nature, there should be various classes of them. The business share (ownership interest) in the Limited Liability Company is set percentage and one shareholder may own only one business share (See Tab. 1), which represents the rights and duties of each shareholder and his participation in the company. The shares of the Limited Companies in the United Kingdom are not transferrable by the deal. The director issues a share certificate, what is a confirmation about holding the shares. (Baňouch, 2001, IPodnikatel.cz, 2013)

The numeric value of capital is the minimum at which company should have a property which guarantees that third parties claim will be repaid. The registered capital must be maintained throughout the life of the corporation. (Eliáš, Pokorná, Dvorák, 2010) Registered capital, unlike business property, is essentially an accounting variable that is largely unrelated to the real asset situation. The actual value of business assets depends on the results of its management. It can be higher or lower than the registered capital. (Ovečková, 2012)

The shared capital in the United Kingdom has special character. A capital written in the Memorandum of Association is called nominal capital. It concerns issued or subscribed share capital and unissued capital. Issued capital consists of paid up capital and 
unpaid or uncalled capital. When Private Limited Company enters the process of liquidation, there is still amount of unpaid capital, which is also named reserve capital. The unissued capital entitles company to raise issued or subscribed capital of the company to the amount of nominal capital. Synonym of issued or subscribed capital is our registered capital. (Baňouch, 2001)

The capital requirements in some European Union countries are less rigid in comparison with public companies. The United Kingdom traditionally follows a liberal approach, according to which no minimum capital is required to incorporate a private company. For example, in France minimum capital as a requirement to form a SARL (société à responsabilité limitée) was abolished in 2003. In Germany there is a variation of the GmbH (Gesellschaft mit beschränkter Haftung) without minimum capital (25 000 EUR) called Unternehmergesellschaft (haftungsbeschränkt) or UG (haftungsbeschränkt) which has considerable restrictions imposed on the distribution of the profits in order to enable the company to progressively accumulate the minimum nominal capital required for a normal $\mathrm{GmbH}$. The capital required to form a private company varies from zero, which applies to the Ltd, the SARL and the UG (haftungsbeschränkt) up to 25000 EUR for the $\mathrm{GmbH}$. (Dorrestein, Monteiro, Teichman, Werlauff 2009) In our opinion the development of private companies with limited liability in European area is progressively moving towards reducing the minimum amount of registered/shared capital. The trend can be explained by the fear that businesses seem to prefer incorporating abroad where they would find less restrictive requirements than the ones they would have to comply with in their own jurisdiction. (Dorrestein, Monteiro, Teichman, Werlauff 2009)

Since 1st January 2017 a new form of business companies under the Commercial Code, Simple Joint Stock Company, can be established in the Slovak republic. Simple Joint Stock Company is ideal form for start-ups. Advantages of a hybrid form of Joint Stock Company and Limited Liability Company are low capital requirement (1 EURO), possibility of foundation single-member (individual or legal entity) company ( $\S 220 t(1,2$ CC), no obligation to form Supervisory Board ( $\$ 220 z e$ CC), option to issue specific classes of shares such as the right to a larger share of the profit ( $\$ 220 \mathrm{i}(3) \mathrm{CC}$ ) and to enter into agreements among shareholders regarding their rights and obligations for instance tag-along right or drag-along right ( $\$ 220 \mathrm{w}$ CC). In the first year of its existence only 54 Simple Joint Stock companies were founded. (Finstat. sk, 2018)

Before the incorporation of the Limited Liability Company, Memorandum of Association must be written. According to the provisions of $\S 110$ (1) CC it contains business name and the registered office of the company, identification of the shareholders, scope of the business (activities), amount of the registered capital, amount of contribution of each shareholder and the manner and period for the payment of the pledged contributions, identification of the company's first executives and the manner in which they will represent the company, identification of the members of the first Supervisory Board, if established, name of the custodian of the contributions, amount of the Reserve Fund, if it is formed upon its establishment, planned costs related to the foundation and the incorporation of the company, advantages to the persons participating in the foundation of the company and other data, if stipulated by law. Limited Liability Company may issue Articles of Association which deals with company's internal organization and matters included in Memorandum of Association more detailed. (§ 110 (2) CC) In single-member Limited Liability Companies a Founding Agreement must be written. It must contain the same essential parts as the Memorandum of Association. (§ 57 (3) CC) 
The application for registration in the United Kingdom must state the company's proposed name, whether the registered office will be situated in England and Wales, Wales, Scotland or Northern Ireland, whether the member's liability is to be limited and if so, whether by shares or by guarantee and whether the company is to be a public or a private company. Application for association of a company must contain a statement of capital and initial shareholdings (if a company limited by shares), a statement of the company's proposed officers, including the proposed company secretary (if the company is a public company or where a private company chooses to have a company secretary), a statement of initial significant control (it must state whether there will be anyone who will count for purposes of register of people with significant control over company as a person whose particulars would be required to be entered in the company's PSC register), a statement of the intended address of the company's registered office and a copy of any proposed Articles of Association unless the intention is to rely on the model default articles. (Hannigen, 2016)

An application for registration must be accompanied by a Memorandum of Association, which is a document stating that the subscribers wish to form a company under the Companies Act 2006 and agree to become members of the company and to take at least one share each. Previously the memorandum of association was an important external/facing document telling the outside world the key facts about the company. Now the memorandum simply records the identity of the original founders of the company and indicates how many shares they took on formation. In many cases, the original founders will be formation agents and so the document will have no continuing relevance. (Hannigen, 2016) Articles of Association are written rules about running the company agreed by the shareholders and the directors or the company secretary. Both documents are necessary to register the company with the Companies House. (GOV.UK, 2018)

The Limited Liability Company is established when the Memorandum of Association is signed by all shareholders. Signatures of the founders must be officially authenticated. The Articles of Association are possible but not compulsory. For the registration of the Private Limited Company with Companies House both Memorandum of Association and Articles of Association to be written. By the online registration standard Articles of Association are used. There is no obligation to officially verify a single signature, everything is based on the principle of "good faith". There is also no Trade Licencing Office in the Great Britain, subjects of business are registered with the Companies House as they are in the Articles of Association. (IPodnikatel.cz, 2013)

Private Limited Company in the United Kingdom can be registered by post, which takes from 8 to 10 days and registration fee is $40 \mathrm{f}$. Faster registration by post in one day is also possible, if the costs $100 £$ are paid and application gets to the Companies House by 3 pm. Private Limited Company by Shares can be incorporated online by using standard Articles of Association (model articles). Online registration costs only $12 £$ and company is usually registered within 24 hours (GOV.UK, 2018), 2 working days are maximum (Ltdcompany.co.uk, 2018).

The court fee for the registration of the Limited Liability Company in the Commercial Register is 300 EUR (Scale of Court Fees, Slovak National County Act No. 71/1992 Coll. on Court Fees and the Court Fee for a Copy from the Criminal Record, as amended). If the company is registered electronically court fee is reduced by half. The Register 
Court makes an entry within 2 working days of receiving the application for registration (§ 8 (1) Act No. 530/2003 Coll. Commercial Register Act, as amended)

We may notice that registration fees of the Private Limited Company are significantly lower than registration fees of the Limited Liability Company. The time of online registration with Companies House is very similar to the time of registration in the Commercial Register. When comparing the time and amount of the registration fee, the online registration of Private Liability Companies is the most advantageous (See Tab. 1).

The proposal contained harmonised process of the company's registration via a registration template and facultative online registration connected with unit template of Articles of Association. Registration should take 3 days, if the company would be newly established. The minimum shared capital should be 1 EUR, or equivalent of 1 unit of currency of the member state, where euro isn't national currency. There was no obligation to build up legal reserves, but it was possible to build voluntary reserves in accordance with Articles of Association. Protection of the creditors should be ensured by obligation of the SUP directors (or the SUP single founder) to provide distributions. The main intention of the proposal was to diminish set-up and operational costs of the company. (Eur - lex.europa.eu, 2014)

The Limited Liability Company is obligated to establish a reserve fund which can be used to cover company's losses unless otherwise stipulated by law. The purpose of the reserve fund is to save certain parts of the profits at a time when the company is successful in business as to cover future losses through its less successful business. It is a certain reserve, which together with the registered capital provides certainty to creditors. There must be some proportionality between the value of the registered capital and the amount of the reserve fund. (Ovečková, 2012) If the reserve fund is not established upon the registration of the company in the Commercial Register, the company is obligated to establish it from net profits reported in ordinary financial statements for the year in which it shall produce profits for the first time, at the amount equal to at least $5 \%$ of net profits, but not more than $10 \%$ of the registered capital. ( $\$ 124$ CC)

There is no obligation to form reserve fund in Private Liability Company by Shares nor in the single - member Private Limited Liability Company. In our opinion the general trend is a company with limited liability of the shareholders, with low registered/shared capital and informal setting-up process without the obligation to create reserves (reserve fund). No obligation to establish the reserve fund in combination with low shared capital was the proposal on single-member Private Limited Liability Companies was rejected by the European Economic and Social Committee.

\subsection{Company Bodies}

The supreme body of the Limited Liability Company is a General Meeting consisting of all shareholders. ( $\S 125$ (1) CC) The statutory body is constituted of one or more executives acting on behalf of the company. If there are more executives, each of them is entitled to act individually on behalf of the company, unless the Memorandum of Association stipulates otherwise. The executives are appointed by the General Meeting from shareholders or other individuals. Hold the office of executive of the company may 
only individuals. ( $\S 133 \mathrm{CC}$ ) Althought shareholders are only legal entities, the manager, can only be a natural person, who has reached the age of 18 , who has a full legal capacity and is irreproachable. (Suchoža, 2016) The register court at the registration of the first executives doesn't examine legal capacity of the executives or their integrity. The examination of these assumptions is ensured by the law for example in obtaining a Certificate of Trade Authorisation. (Patakyová, 2016) Individuals also may not be disqualified by the court from being a member of the statutory body or a supervisory body. ( $\S 13 a$ CC) A Supervisory Board, which is not obligatory body of the company, must have no less than 3 members elected by the General Meeting. Executives can't hold the office of member of the Supervisory Board. (§§ 137, 138 CC)

Decisions of Private Limited Company in the United Kingdom are also made at General Meetings, where shareholders or other entitled persons exercise their right to vote and right to speak. The chairman of the meeting is appointed by directors, when he is not not present, the meeting must appoint the chairman, which will be the first business of the meeting. No business other than the appointment of the chairman is to be transacted at the General Meeting if the persons attending it don't constitute a quorum. A management body, Board of Directors, consists of one or more directors, at least one director must be a natural person, who must be over 16 and cannot be disqualified from being a director under Company Directors Disqualification Act 1986. (Baňouch, 2001, Patakyová, 2016, GOV.UK, 2018) A company secretary is not more obligatory (unlike the Public Limited Companies). It can be used to take on some of the director's (chairman's) responsibilities. Directors are taken decisions collectively. Any decision of the directors must be either a majority decision or a unanimous decision. If the company has only one director, general rules about decision-making don't apply. (GOV.UK, 2014) The responsibilities at the head of the company are divided between the chairman of the board who is responsible for leadership of the board and the chief executive with responsibility for running of the business. These roles should not be exercise by the same individual and the chief executive of the company should not move up to become chairman. The division of responsibility between them should be clearly established, set out in writing and agreed by the board. (Hannigen, 2016)

If there is only one shareholder in the Limited Liability Company in the Slovak republic, he exercises the scope of powers of the General Meeting. Unless the Commercial Code stipulate otherwise, decisions of the only member during the exercise of functions of the General Meeting must be in writing and must be signed by the only member. ( $\S$ 132 CC) In decisions with more serious legal consequences such as increasing or reduction of the registered capital, appointing and recalling executives, changing of the legal form of the company, winding-up of the company, must be shareholder's signature officially authenticated. If the only shareholder is executive of the company at the same time, agreements made between this shareholder and the company must be in writing. (Čurila, 2017)

According to the proposal decisions of the single member executing powers of the General Meeting should be recorded in writing, records of taken decisions should be kept for 5 years, agreements between single member and the company should be also recorded in writing. Member states might decide not to apply stated to contracts concluded under market conditions in the ordinary course of business which were not detrimental to the single-member company. (Eur - lex.europa.eu, 2014) Management body of the SUP consisted of one or more directors. Directors should be natural persons or 
legal persons, where allowed by applicable national law. A natural person who is disqualified by either the law or a judicial or administrative decision of the member state of registration could not act as a director. The single member might become a director.

Directors might exercise all the powers of the SUP that are not exercised by the single member or, where applicable, by the Supervisory Board. Directors might represent the SUP individually, including entering into agreements with third parties and in legal proceedings, unless the Articles of Association provide for joint representation. (Eur lex.europa.eu, 2014)

A Supervisory Board is not compulsory body of the Limited Liability Company. Although the Companies Act 2006 does not categorise directors into executive and nonexecutive directors, modern corporate practice, in the light of corporate governance reforms, recognises the division between two types of directors. Executive directors are generally full-time officers of the company. The Articles typically give extensive management powers to them and they will usually have separate service contracts with the company. Non-executive directors are appointed to the boards of larger companies to act as monitors of the executive management and they are typically part-time appointments. (Dignam, Lowry, 2014) At least half the board, excluding the chairman, should be independent non-executive directors while smaller companies should have at least two independent non-executive directors. (Hannigen, 2016)

The proposal just mentioned powers of the Supervisory Board of the member states where it is created. The difference is that members of the statutory body of the Limited Liability Company may be only individuals, in Private Limited Company at least one member must be a natural person, in SUPs nature of the statutory body depends on legislation of the member state (See Tab. 1). Executives of Limited Liability Company acts individually unless the Articles of Association stipulates otherwise. The directors of the Private Limited Company take decisions collectively (majority or unanimous decisions). Decisions of single-member companies should be in writing, agreements between the single member and the executive (director) at the same time and the company must be in writing, too. In addition, in more serious decisions of the single member executing powers of the General Meeting must be signature of the single-member officially verified under the Commercial Code.

Tab. 1 The comparison between Limited Liability Company, Private Limited Company by Shares and Societas Unius Personae (SUP)

\begin{tabular}{|l|l|l|l|}
\hline & $\begin{array}{l}\text { Limited Liability } \\
\text { Company }\end{array}$ & $\begin{array}{l}\text { Private Limited } \\
\text { Company }\end{array}$ & $\begin{array}{l}\text { Societas Unius } \\
\text { Personae (SUP) }\end{array}$ \\
\hline $\begin{array}{l}\text { Minimum number of } \\
\text { shareholders }\end{array}$ & 1 & 1 & 1 \\
\hline Nature of shareholders & $\begin{array}{l}\text { natural person/ } \\
\text { legal entity }\end{array}$ & $\begin{array}{l}\text { natural person/ legal } \\
\text { entity }\end{array}$ & $\begin{array}{l}\text { natural person/ } \\
\text { legal entity }\end{array}$ \\
\hline $\begin{array}{l}\text { Maximum number of } \\
\text { shareholders }\end{array}$ & 50 & not stated & - \\
\hline
\end{tabular}




\begin{tabular}{|l|l|l|l|}
\hline $\begin{array}{l}\text { Minimum } \\
\text { registered/shared capital }\end{array}$ & 5000 EUR & any value $(1 £)$ & $\begin{array}{l}1 \text { EUR/1 unit of } \\
\text { currency of the } \\
\text { member state }\end{array}$ \\
\hline
\end{tabular}

\begin{tabular}{|c|c|c|c|}
\hline $\begin{array}{l}\text { Minimum shareholder's } \\
\text { contribution/price of } \\
\text { individual share/single- } \\
\text { share }\end{array}$ & 750 EUR & any value $(1 £)$ & $\begin{array}{l}1 \text { EUR/ } 1 \text { unit of } \\
\text { currency of the } \\
\text { member state }\end{array}$ \\
\hline $\begin{array}{l}\text { Number of business } \\
\text { share/shares for one } \\
\text { shareholder }\end{array}$ & 1 & Unlimited & 1 \\
\hline Classification of shares & $\begin{array}{l}\text { the unified nature } \\
\text { of the share }\end{array}$ & $\begin{array}{l}\text { types (classes) of } \\
\text { shares }\end{array}$ & single share \\
\hline Split of the share & share can be split & share can't be split & share can't be split \\
\hline Statutory body & $\begin{array}{l}\text { one or more } \\
\text { executives }\end{array}$ & $\begin{array}{l}\text { one or more } \\
\text { directors }\end{array}$ & $\begin{array}{l}\text { one or more } \\
\text { directors }\end{array}$ \\
\hline $\begin{array}{l}\text { Nature of the statutory } \\
\text { body }\end{array}$ & only individuals & $\begin{array}{l}\text { at least one director } \\
\text { must be a natural } \\
\text { person }\end{array}$ & $\begin{array}{l}\text { individual or legal } \\
\text { person (depends } \\
\text { on the member } \\
\text { state's legislation) }\end{array}$ \\
\hline The supreme body & General Meeting & General Meeting & $\begin{array}{l}\text { single-member is } \\
\text { executing powers } \\
\text { of the General } \\
\text { Meeting }\end{array}$ \\
\hline Supervisory Board & facultative & $\begin{array}{l}\text { non-executive } \\
\text { members of the } \\
\text { Board of Directors } \\
\text { monitor executives } \\
\text { members }\end{array}$ & $\begin{array}{l}\text { facultative, } \\
\text { depends on the } \\
\text { member state's } \\
\text { legislation }\end{array}$ \\
\hline Reserve fund & compulsory & - & Facultative \\
\hline Online registration & facultative & Facultative & Facultative \\
\hline Registration costs & 300 EUR & $\begin{array}{l}40 £, 100 £ \\
\text { registration by post }\end{array}$ & $\begin{array}{l}\text { depends on the } \\
\text { member state }\end{array}$ \\
\hline $\begin{array}{l}\text { Advantages of online } \\
\text { registration }\end{array}$ & $\begin{array}{l}1 / 2 \text { of registration } \\
\text { costs }\end{array}$ & $\begin{array}{l}12 £ \text { (online } \\
\text { registration) } \\
\text { significantly shorter } \\
\text { time of registration }\end{array}$ & $\begin{array}{l}\text { set-up costs } \\
\text { reduction }\end{array}$ \\
\hline $\begin{array}{l}\text { Time for registration of } \\
\text { the company }\end{array}$ & 2 working days & $\begin{array}{l}8-10 \text { days, } 1 \text { day } \\
\text { (by post) } \\
24 \text { hours }-2 \text { working } \\
\text { days (online } \\
\text { registration) }\end{array}$ & 3 days \\
\hline
\end{tabular}

Source: Own processing according to H. Baňouch, 2001, p. 375 


\section{Conclusion}

Private Company Limited by Shares and Limited Liability Company are both separate entities with full legal capacity. They have similar features such as relatively low registered/shared capital (5000 EUR/1EUR), simple structure of company bodies (at least one executive/director and General Meeting, Supervisory Board is not compulsory under the Commercial Code/in the United Kingdom system of non-executives and executives is developed) and possibility of foundation of single-member companies (by natural person or legal entity). Also single-member Private Limited Liability Company (SUP) under the proposal used combination of these characteristics (shared capital it the amount of 1 EUR or one unit of currency of the member state, the only shareholder exercises powers of the General Meeting, creation of the Supervisory Board depends on the legislation of the member state).

The reserve fund is obligatory only in the Limited Liability Company, there is no notice about the reserve fund in the provisions of Private Limited Company by Shares. The establishment of the reserve fund in SUPs was only facultative, protection of the creditors was secured via obligations of directors in profit distributions.

Online registration is/was facultative and usually connected with unit template of Articles of Association (Private Company/SUP), significant reduction of registration costs (Limited Liability Company, Private Limited Company) in combination with short time of registration (Private Limited Company) (For more details see Tab. 1).

Another attractive side of the Private Limited Company by Shares and Limited Liability Company as well as single-member Private Limited Liability Company is/was that registered office and the principal place of business don't need to be in the same member state according to the EU legislation.

The European Economic and Social Committee (thereinafter only "EESC") which rejected the proposal had criticized minimum reserved/shared capital in the amount of 1 EUR together with no obligation to create reserves in SUPs. Verification of the identity of the founder should be required by online registration. Further the EESC suggested the unification of registered office and principal place of business to provide unify rules for SUPs including rights of employees to co-decision. According to the EESC SUPs should be multinational companies and the target groups of the proposal would be only small and middle enterprises with cross-border activities.

In our opinion fast, simple and inexpensive online registration involving unit template of registration and Articles of Association, low registered or shared capital, foundation of single-member companies with limited liability, where only member is also director or executive of the company is not only the presence, but also the future of companies with limited liability. The question is: "What about creditors, consumers and providers? Is registered/shared capital 1 EUR without obligation to make reserves enough to protect them? From our point of view not high amount of registered capital together with obligation to make reserves is optimal. The Mini-GmbH in Germany needs only minimum registered capital, but there is obligation to create reserves in the amount of $25 \%$ of profits. The inspiration from the British legislation to us should be mainly informal and not expensive way of incorporation of Private Limited Companies by Shares. It is the reason why they are so popular. The proposal of European Parliament and 
Council for Directive on single-member Private Limited Liability Companies was withdrawing, we expect that legislation of Private Limited Companies will be governed by national law and that "regulation competition" on the side of legislators and "company law shopping" on the side of businessmen will continue.

\section{References}

Baňouch, H. (2001). Private Company limited by shares - britská obchodní společnost odpovídajíci naší společnosti s ručením obmedzeným. Časopis pro právni vědu a praxi, 9(4), 367-377.

CEVE. cz (2013). Společnost Ltd. (Limited) ve Velké Británii a její specifika. Retrieved June 19, 2018, from http://www.ceve.cz/cs/spolecnost-llp-britanie

Čurila, D. (2017). Postavenie jediného spoločníka obchodnej spoločnosti. Dane a úctovníctvo v praxi: mesačník plný informácií z oblasti daní, práva a účtovníctva, 22(11), 22-25.

Davies, P. Worthington, S. (2012). Principles of modern company law. Ninth edition, London: Sweet \& Maxwell

De Grandes Pascual, L. (2018). Legislative train schedule. European Parliament. Single-member private limited companies (Societas Unius Personae)/2014. Retrieved September 24, 2018, from http://www.europarl.europa.eu/legislativetrain/theme-connected-digital-single-market/file-single-member-companies

Dignam, A., \& Lowry, J. (2014). Company Law. Eight edition. Oxford: Oxford University Press.

Dorrestein, A., Monteiro, T., Teichman, Ch., \& Werlauff, E. (2009). European Corporate Law. Second Edition, Kluwer Law International.

Eliáš, K., Pokorná, J., \& Dvořák, T. (2010). Kurs obchodního práva. Obchodní společnosti a družstva. Praha: C. H. Beck.

Eur - lex.europa.eu (2014). EUR-Lex - 52014PC0212 - EN - EUR-Lex. Proposal for a Directive of the European Parliament and of the Council on single-member private limited liability companies. Retrieved January 25, 2018, from http://eur-lex.europa.eu/legal-content/SK/TXT/?uri=CELEX\%3A52014PC0212.

Finstat.sk. (2018). Štatistika počtu vzniknutých a zaniknutých firiem. Retrieved October 10, 2018, from https://www.finstat.sk/analyzy/statistika-poctu-vzniknutych-azaniknutych-firiem.

GOV.UK (2014). Model articles for private companies limited by shares. Retrieved January 29, 2018, from https://www.gov.uk/government/publications/model-articlesfor-private-companies-limited-by-shares.

GOV.UK (2018). Set up a private limited company. Retrieved January 25, 2018, from https://www.gov.uk/limited-company-formation.

Hannigan B. (2016) Company Law, Fourth Edition, Oxford: Oxford University Press.

IPodnikatel.cz (2013). Jak založit firmu ve Velké Británii. Retrieved June 20, 2018, from http://www.ipodnikatel.cz/Zalozeni-obchodni-spolecnosti/jak-zalozit-firmuve-velke-britanii/Akcie-v-Anglii.html 
Ltdcompany.co.uk (2018). Private Limited Company (UK). Advantages of Private Ltd Company UK. Retrieved January 30, 2018, from http://www.Itdcompany.co.uk/company-formation/private-limited-company/

Málek, O. (2017). Legislatívní soutěž v inkorporačním právu v EU: Cesta ke zvyšování konkurencieschopnosti trhu. In: Právo v podnikání vybraných členských států Evropské Unie - sborník příspěvků k IX. ročníku mezinárodní vědecké konference, 2017, (s. 167-172). Praha: Troas.

Ovečková, O. (2012). Obchodný zákonník : komentár. Bratislava: Iura Edition.

Pala, R. (2004). Kde sa oplatí založit' eseročku. Retrieved June 19, 2018, from https://www.etrend.sk/podnikanie/kde-sa-oplati-zalozit-eserocku.html

Patakyová, M. (2016). Obchodný zákonník : komentár. Praha: C. H. Beck.

Suchoža a kol. (2016). Obchodný zákonník a súvisiace predpisy. Komentár. Bratislava: Eurounion. 